\title{
Genetic parameters and trends for reproductive traits in Blanco Orejinegro cattle from Colombia
}

\section{Parâmetros e tendências genéticas para características reprodutivas no gado Blanco Orejinegro da Colômbia}

\author{
Sindy Liliana Caivio-Nasner ${ }^{1 *}$; Albeiro López-Herrera ${ }^{2}$; Luis Gabriel \\ González-Herrera; J Juan Carlos Rincón Flórez ${ }^{3}$
}

\section{Highlights}

Blanco Orejinegro females have good phenotypic longevity.

Blanco Orejinegro cattle have significant levels of inbreeding.

The calving interval shows negative genetic trends.

The calving interval trait shows inbreeding depression.

\begin{abstract}
The Colombian creole cattle breed Blanco Orejinegro (BON) is an important zoogenetic resource, but there is little knowledge about the genetic parameters and trends of its reproductive traits. Therefore, the aim of this study was to estimate parameters for the reproductive traits calving interval $(\mathrm{Cl})$, age at first calving (AFC), gestation duration (GD) and genetic trends for $\mathrm{Cl}$ in the $\mathrm{BON}$ breed. Genealogy information from 7,799 animals was used, and employing the MTDFREML program, the components of the variance, heritability $\left(h^{2}\right)$, repeatability (rep), and estimated breeding values (EBV) for $C l(n=3308), A F C(n=729)$, and GD $(n=306)$ were estimated, in addition to the inbreeding coefficient $(F)$ of the population. Genetic trends were established through linear regression using $\mathrm{R}$ software. Finally, the animals were classified as inbred $(F>0)$ and noninbred $(F=0)$, and the effect of inbreeding on reproductive performance was established through a generalized linear model using the $R$ program. An average $F$ value of $4.41 \% \pm 0.06$ was observed. The $\mathrm{h}^{2}$ for $\mathrm{Cl}$ was $0.11 \pm 0.03$ with a rep of $0.15 \pm 0.04$; for $A F C, h^{2}$ was $0.00 \pm 0.05$; and for $G D, h^{2}$ was $0.00 \pm 0.08$. The genetic trend for $\mathrm{Cl}$ was -0.01 days/year. Finally, for $\mathrm{Cl}$, inbreeding depression was evident; this trait increased when inbreeding increased. These results indicate an important environmental influence on reproductive traits. The heritability estimate for $\mathrm{Cl}$ suggests that little genetic progress could be achieved through selection. The evidence of inbreeding depression raises the need to control inbreeding to conserve
\end{abstract}

1 Magíster en Biología Molecular y Biotecnología, Grupo de Investigación Biomolecular y Pecuaria (BIOPEC), Universidad Tecnológica de Pereira, UTP, Pereira, Risaralda, Colombia. E-mail: sindy93566@utp.edu.co

2 Profs. Drs., Universidad Nacional de Colombia sede Medellín, Grupo de Investigación Biodiversidad y Genética Molecular, BIOGEM, Medellín, Antioquia, Colombia. E-mail: alherrera@unal.edu.co, luggonzalezhe@unal.edu.co

3 Prof. Dr., Universidad Nacional de Colombia sede Palmira, Grupo de Investigación BIOGEM, Palmira, Valle del Cauca, Colombia. E-mail: jcrincon@unal.edu.co

* Author for correspondence

Received: Oct. 06, 2020 - Approved: Apr. 16, 2021 
this genetic resource.

Key words: Consanguinity. Heritability. Inbreeding depression. Genetic evaluation.

\section{Resumo}

O gado crioulo colombiano Blanco Orejinegro (BON) é um importante recurso zoogenético, mas ainda há desconhecimento sobre os parâmetros e tendências genéticas das características reprodutivas dessa raça. Portanto, o objetivo deste estúdio foi estimar parâmetros e tendências genéticas para características reprodutivas intervalo de partos (IDP), idade ao primeiro parto (IPP) e duração da gestação (DG) na raça BON. A informação da genealogia de 7,799 animais foi usada. Utilizando o programa MTDFREML foram estimados os componentes de variância, herdabilidade $\left(h^{2}\right)$, repetibilidade (rep) e valores genéticos (VGE), para IDP ( $n=3308)$, IPP ( $n=729)$ e DG $(n=306)$, além do coeficiente de endogamia (F) na população. As tendências genéticas foram determinadas por regressão linear usando o software R. Finalmente, os animais foram classificados como endogâmicos ( $F>0)$ e não endogâmicos $(F=0)$ e o efeito da endogamia no desempenho reprodutivo foi determinado usando um modelo linear generalizado usando R. Observouse um $\mathrm{F}$ médio de $4,41 \%+0,06$. A h $\mathrm{h}^{2}$ para IDP foi $0,11 \pm 0,03$ com uma repetibilidade de $0,15 \pm 0,04$; para IPP a $h^{2}$ foi $0,00 \pm 0,05$; e para $D G$ a $h^{2}$ foi $0,00 \pm 0,08$. A tendência genética para IDP foi $-0,01$ dias/ano. Finalmente, para o IDP, a depressão por endogamia foi evidente, aumentando o IDP com o aumento da endogamia. Os resultados indicam uma importante influência ambiental nas características reprodutivas. A herdabilidade estimada para o IDP sugere que pouco ganho genético pode ser alcançado através da seleção, embora a depressão endogâmica evidencie a necessidade de controlar a consanguinidade para conservar o recurso genético.

Palavras-chave: Consanguinidade. Herdabilidade. Depressão endogâmica. Avaliação genética.

\section{Introduction}

Colombia has the highest creole cattle diversity in South America, with eight recognized creole breeds and two synthetic breeds. These animals originated from cattle brought by the Spanish to the Americas in the late fifteenth century from the Iberian Peninsula and possibly later from Africa and they spread throughout the country (Martínez et al., 2012a). One of these native breeds is the Blanco Orejinegro (BON), which has had more than 500 years of adaptation to the conditions of the Colombian tropics (Martínez et al., 2012a), with low levels of artificial selection (Martínez et al., 2012b). For many years, cattle ranching in Colombia consisted exclusively of creole animals, among which the BON breed stands out (Martínez et al., 2012b). This breed has outstanding productive-level advantages, such as resistance to common diseases found in the country and adaptability to its severe and extreme climatic conditions.

Individuals with $\mathrm{BON}$ are characterized by being meek with good reproductive traits such as high fertility, easy calving, good maternal ability, and longevity. These traits have a substantial effect on production costs and constitute an adaptive advantage compared to nonnative cattle (Martínez et al., 2012b); however, overall, there is a lack of knowledge about the benefits of this breed. This creole resource is of high economic value for cattle farming in Colombia and 
similar tropical regions and may be useful when considering the challenges associated with climate change. These issues can lead to increased production costs if nonnative animals with little adaptability and resistance to tropical conditions are extensively used, as then, the environmental conditions of the production system must be improved without affecting productivity (Canaza-Cayo, Lopes, Cobuci, Martins, \& Silva, 2018). For this reason, the conservation of creole cattle germplasm is essential; despite this, the use of nonnative breeds has been increasing to obtain higher productive indexes, decreasing the populations of creole cattle, including those of the BON breed, for which not only their reproductive traits are unknown but also their consanguinity levels and its effects on reproduction are unclear.

Reproduction is a sign of adaptation and is key in genetic resource conservation and animal-origin food production (RojasDowning, Nejadhashemi, Harrigan, \& Woznicki, 2017). Variations in reproductive performance depend on environmental and genetic factors (Eler, Bignardi, Ferraz, \& Santana, 2014), and understanding this variation can be a decisive factor in conservation. Therefore, genetic evaluation programs are important, especially when considering reproductive and adaptability traits. These programs seek to establish the variation proportion of a trait according to its genetics, considering nongenetic (environmental) factors that influence its expression to increase the frequencies of genes favorable for a specific trait (Quijano \& Echeverri, 2016). This is carried out through selection, utilizing estimated breeding values. It is necessary to have information from animal or progeny records to estimate genetic parameters and to determine if it is possible to achieve the genetic improvement of a particular trait through selection. The genetic parameters used in breeding programs are heritability, repeatability, genetic correlation, and inbreeding.

Knowledge of genetic parameters, genetic trends, and inbreeding depression is essential, as it helps establish a basis to justify the decision-making process in selection, management, and nutrition programs to improve reproductive efficiency in BON animals. Accordingly, this study aimed to estimate the parameters of the reproductive trait calving interval $(\mathrm{Cl})$, age at first calving (AFC), gestation duration (GD) and genetic trends for $\mathrm{Cl}$ of Colombian $\mathrm{BON}$ cattle.

\section{Materials and Methods}

The Ethics Committee for the Care and Use of Animals of Universidad Nacional de Colombia, Medellín campus, approved this study through CICUA-005 of 2016.

The BON animal records analyzed in this research were collected between 1981 and 2018 from 14 Colombian herds registered in the creole breed association Asocriollos, which operates in six states of Colombia (Antioquia, Caldas, Cundinamarca, Meta, Risaralda, and Tolima). The sites where the BON herds are maintained have average temperatures between 14 and $25 \mathrm{C}^{\circ}$ and altitudes from 800 to 2,500 meters above sea level. There is a prevalence of pastures of Pennisetum clandestinum (Kikuyo), Brachiaria sp. (Brachiaria), Cynodon plectostachyus (African star grass), and Paspalum sp. (native grasses) under rotational grazing (from semiextensive to intensive) and mineral supplementation. Natural mating is the reproduction method that predominates. 
The following reproductive traits were evaluated: calving interval (Cl), age at first calving (AFC), and gestation duration (GD). The trait maximum number of calvings (NCmax) was considered, but due to a lack of information $(n=102)$ and because it all came from a single herd, it was difficult to model and obtain reliable heritability results for this trait. Therefore, this information was only used descriptively, considering that longevity is a trait attributed to $\mathrm{BON}$, but with little concrete information. The data were edited and analyzed using the R program version 3.4.3 (R Core Team [R], 2019), eliminating doubtful information, repeated identifications, and extreme values, i.e., three standard deviations above and below the mean of each trait. Animals were chosen based on their identification, birth date of the cow and calf, date of fertile service, date and calving number, sex of the calf, weight at birth, and calf weaning.

This study is a pioneering work and is the most representative of the BON cattle breed so far compared to other studies, as it employs all of the information from 14 herds from Colombia with complete pedigrees. Genealogy information included 7,799 animals (10 generations), with a maximum paternal family size of 252 animals and 35 animals for the maximum maternal family size. Ten sires with the highest number of offspring added 1,735 descendants. Overall, 396 sires and 2,140 dams were reported. The individual inbreeding coefficient $(F)$ was obtained using the MTDFNRM program from the MTDFREML set of programs (United States Department of Agriculture [USDA], 2017).

Database editing provided 3,308 records for $\mathrm{Cl}, 729$ for $\mathrm{AFC}$, and 306 for GD. Levene and Shapiro-Wilk tests were used per trait to evaluate the assumptions of homoscedasticity and the normality of residuals, respectively. Then, a descriptive analysis was performed, estimating the mean, standard deviation, and coefficient of variation (CV) of all of the traits using R software (R, 2019). The analysis database included the following variables: herd, birth year of the cow, calving year, calving number $(\mathrm{CN})$ and sex of the calf, birth weight, calving season, and cow birth season. The last two variables differ because they occur at different times and can influence the variability of the traits. The calving season and the cow birth season comprised two rainy and two dry periods. The first rainy period occurred between April and June, and the second occurred between October and December. The dry periods went from January to March and from July to September.

The model selected to be used in the genetic evaluation for each trait was described in a previous analysis by González Herrera et al. (2020). These authors tested different models to identify those that best fit the variability description of the traits based on the goodness-of-fit criteria of the models, according to a lower Akaike Information Criterion (AIC), Bayesian Information Criterion $(B I C)$, and higher $R^{2}$ values. Moreover, contemporary groups (CG) were established, considering a minimum of five observations per CG. The CGs were formed differently for each trait, considering that all showed different conditions, and therefore, they cannot be defined in the same way. However, many CGs had variables in common; thus, for $\mathrm{Cl}$, the $\mathrm{CG}$ was formed from the concatenation of the herd, calving year, and calving season; for AFC, the CG was comprised of the herd, calving season, and birth year of the cow; for GD, the CG included the calving year, calving season, 
and sex of the calf. The models used for each of the reproductive traits are described below.

$$
\begin{aligned}
& \text { Model for } \mathrm{Cl}_{\mathrm{i}} \mathrm{Y}_{\mathrm{ijkl}}=\mu+\mathrm{CG}_{\mathrm{i}}+\mathrm{Cn}_{\mathrm{j}}+\mathrm{Bw}_{\mathrm{k}} \\
& +\mathrm{By}_{1}+\varepsilon_{\mathrm{ijkl}} \\
& \text { Model for AFC: } Y_{\mathrm{ij}}=\mu+\mathrm{CG}_{\mathrm{i}}+\mathrm{Bw}_{\mathrm{k}}+\varepsilon_{\mathrm{ij}} \\
& \text { Model for GD: } Y_{\mathrm{ij}}=\mu+\mathrm{CG}_{\mathrm{i}}+\mathrm{Cn}_{\mathrm{j}}+\varepsilon_{\mathrm{ij}}
\end{aligned}
$$

where $\mathrm{Y}_{\mathrm{ijkl}}$ : trait to evaluate (Cl, AFC, or GD), $\mu$ : population mean of the trait, CGi: contemporary group (as defined above, $\mathrm{i}=1,2,3, \ldots, \mathrm{i}), \mathrm{C} n_{\mathrm{j}}$; fixed effect of the $j$-th calving number $(j=1,2, \ldots$, 14), Bwk: effect of the k-th birth weight of the calf, Byl: fixed effect of the l-th birth year of the cow $(I=1989, \ldots, 2015)$, and $\varepsilon_{i \mathrm{ikl}}$ is the random error associated with each observation.

The variance components and breeding values of each trait were estimated using a univariate animal model due to the data structure and the difficulty of having complete paired information to apply bivariate models. The best linear unbiased predictor (BLUP) methodology was used with the MTDFREML program, as well as the derivativefree restricted maximum likelihood algorithm (Boldman, Kriese, Van Vleck, \& Kachman, 1995). In addition, $h^{2}$ values and repeatability were estimated with their respective standard errors.

The model shown as equation 1 is described by Mrode and Thompson (2014).

$$
y=X b+Z a+W p e+e
$$

where $y$ : observations vector $(\mathrm{Cl}, \mathrm{AFC}$, and $\mathrm{GD}$ ), $b$ : fixed effects vector (for $\mathrm{Cl}$, the following were considered as fixed effects: $\mathrm{By}, \mathrm{CN}$, and $\mathrm{CG}$; birth weight was included as a covariate. Furthermore, a: vector of the additive genetic random effects of the animal, pe: vector of the permanent environmental random effects (for $\mathrm{Cl})$, e: vector of the residual random effect; $X$,
$W$, and $Z=$ incidence matrices that relate the records with the fixed and random effects.

In equation 2 , the matrix describes the model assumptions for the additive genetic, permanent environmental, and residual random effects.

$$
\mathrm{V}\left[\begin{array}{c}
\mathrm{a} \\
\mathrm{pe} \\
\mathrm{e}
\end{array}\right]=\left[\begin{array}{ccc}
\mathrm{A} \sigma_{\mathrm{a}}^{2} & 0 & 0 \\
0 & \mathrm{I} \sigma_{\mathrm{pe}}^{2} & 0 \\
0 & 0 & \mathrm{I} \sigma_{\mathrm{e}}^{2}
\end{array}\right]
$$

where $\sigma_{a}^{2}$ is the additive genetic variance due to direct additive genetic effects, $\sigma_{p e}^{2}$ is the variance of the permanent environmental effect, $\sigma_{a}^{2}$ is the variance of the residual effects, $A$ is the additive kinship matrix, and $I$ is the identity matrix.

Equation 3 describes the mixed model for the best linear unbiased estimator (BLUE) of the measurable functions of $y$ and for the best linear unbiased predictor (BLUP) of $a$ and pe, as described in Mrode and Thompson (2014).

$\left[\begin{array}{c}\mathrm{b} \\ \mathrm{a} \\ \mathrm{pe}\end{array}\right]=\left[\begin{array}{ccc}\mathrm{X}^{\prime} \mathrm{X} & \mathrm{X}^{\prime} \mathrm{Z} & \mathrm{X}^{\prime} \mathrm{W} \\ \mathrm{Z}^{\prime} \mathrm{X} & \mathrm{Z}^{\prime} \mathrm{Z}+\mathrm{A}_{\alpha 1}^{-1} & \mathrm{Z}^{\prime} \mathrm{W} \\ \mathrm{W}^{\prime} \mathrm{Z} & \mathrm{W}^{\prime} \mathrm{Z} & \mathrm{W}^{\prime} \mathrm{W}+\mathrm{I}_{\alpha 2}\end{array}\right]^{-1}=\left[\begin{array}{c}\mathrm{X}^{\prime} \mathrm{y} \\ \mathrm{Z}^{\prime} \mathrm{y} \\ \mathrm{W}^{\prime} \mathrm{y}\end{array}\right]$

where $\mathrm{I}$ is the identity matrix and $\alpha$ is a scalar that relates the residual and genetic variances: $\alpha_{1}=\frac{\sigma_{e}^{2}}{\sigma_{a}^{2}}$ and $\alpha_{2}=\frac{\sigma_{e}^{2}}{\sigma_{p e}^{2}}$ relate the residual and permanent environmental variances.

Equation 4 describes the estimation of repeatability; according to Quijano \& Echeverri (2016), it describes how repeatability was estimated.

$$
\mathrm{r}=\frac{\sigma_{a}^{2}+\sigma_{p e}^{2}}{\sigma_{a}^{2}+\sigma_{p e}^{2}+\sigma_{e}^{2}}
$$


where $\sigma_{a}^{2}$ is the additive genetic variance; $\sigma_{p e}^{2}$ is the permanent environmental variance; and $\sigma_{a}^{2}$ is the variance of the error.

Breeding value means per year were obtained to calculate the genetic trends; through linear regression, the genetic trend over time (in years) was determined and represented in a graph supported by the corresponding regression equations. Finally, from the inbreeding estimates and according to Wright (1922), the animals were classified as inbred $(F>0)$ and noninbred $(F<0)$, and the effect of inbreeding on breeding values was established using a generalized linear model. All these analyses were performed using $R$ software ( $R$, 2019). Genetic values were used as a response variable, and being inbred was employed as a predictor variable.

The inbreeding coefficient calculation described by Wright (1922) is presented below in equation 5 .

$$
R_{X Y}=\sum\left(\frac{1}{2}\right)^{n+n^{\prime}}\left(1+F_{C A}\right) / \sqrt{\left(1+F_{X}\right) \sqrt{\left(1+F_{Y}\right)}}
$$

where $R_{X Y}$ is the relationship coefficient between $X$ and $Y ; n$ and $n^{\prime}$ are the number of generations since $X$ and $Y$, respectively, up to a common ancestor (CA); and FX and Fy are the relationship coefficients for individuals $X$ and $Y$. The inbreeding coefficient of animal $Z$ (descendant of $X, Y$ ) is obtained by adding 1 to the sum of the number of generations

$$
F_{Z}=\sum\left(\frac{1}{2}\right)^{n+n^{\prime}+1}\left(1+F_{C A}\right)
$$

where $F z$ is the inbreeding coefficient of individual $Z$.

\section{Results and Discusion}

In this study, the BON females showed good reproductive efficiency; for $\mathrm{Cl}$, the mean was $469 \pm 112.18$ days. The result recorded in this study was higher than that estimated by Valencia, Aristizabal, Carmona, Martínez and Herrera (2016) in BON cows with more than five calvings ( $450 \pm 85.11$ days). However, the $\mathrm{Cl}$ was lower than that reported in the creole cattle breed Romosinuano, with a $\mathrm{Cl}$ of $553 \pm$ 68 days (Martínez-Rocha, Ramírez-Valverde, Núñez-Domínguez, García-Muñiz, \& ParraBracamonte, 2021), and in other nonnative breeds. For example, a $\mathrm{Cl}$ of 535.50 days was found in Brahmans from Venezuela (Sebastian \& Correa, 2016), and 481.3 days was found in Guzerats (Segura-Correa et al., 2017). On the other hand, for Romosinuano, in the study by Saraz et al. (2013), lower Cl values (422 \pm 131 days) were estimated.

For AFC, the result in the BON population studied was $1,108 \pm 160.23$ days (or 36,9 \pm 5.3 months), which was slightly higher than that in the creole breed Romosinuano (34.56 \pm 3.48 months) (Martínez, Bernal, Blanquicet, \& Sarraz, 2020) but lower than the value reported in another creole cattle breed, Costeño con Cuernos (39 months) (Ossa-Saraz, 1999). However, the estimated $\mathrm{AFC}$ in $\mathrm{BON}$ is high compared with specialized breeds, such as Holstein from Costa Rica at 30.7 months (Aguirre-Valverde, Vargas-Leitón, \& Romero-Zuñiga, 2013), which is maintained under very different intensive conditions.

Regarding The gestation duration, an average of $282.17 \pm 11.07$ days was recorded. The GD of the BON population studied was shorter than that reported in breeds such as Costeño con Cuernos at 288.60 days (Ossa Saraz, 1999) and Korean Hanwoo at 286.39 
days (Lopez, Son, Seo, \& Lim, 2019); this is a critical aspect because the calf will not be very large when born, reducing the possibility of dystocia or calving difficulty.

For the NCmax trait (females), the value was $7.93 \pm 3.10$ calvings on average, with the first calving at 1,108 days and a $\mathrm{Cl}$ of 469 days, i.e., an average longevity value of $4,827.17$ days (13.22 years, assuming 365.24 days/year) for BON cows. Concerning NCmax, there are no reports in this regard, especially in American creole cattle. However, Kern et al. (2014), estimated longevity measures related to productive life and survival at a specified age in Brazilian Holstein cattle. These authors reported productive values up to 84 months of age (7 years), i.e., lower values than those found in the current study.
Overall, the BON cattle from Colombia showed good reproductive traits compared to other native and nonnative breeds, an important aspect required to create adequate strategies to improve reproductive rates in this breed and to implement selection and genetic improvement programs.

The average inbreeding coefficient reported in the evaluated population was $4.41 \%$, showing a considerable level of inbreeding that can affect the performance of animals in terms of reproduction, fertility, and health (Quijano \& Echeverri, 2016). In Figure 1 , inbreeding variation is observed across generations, with low average values in some generations and a progressive decrease in the last three generations.

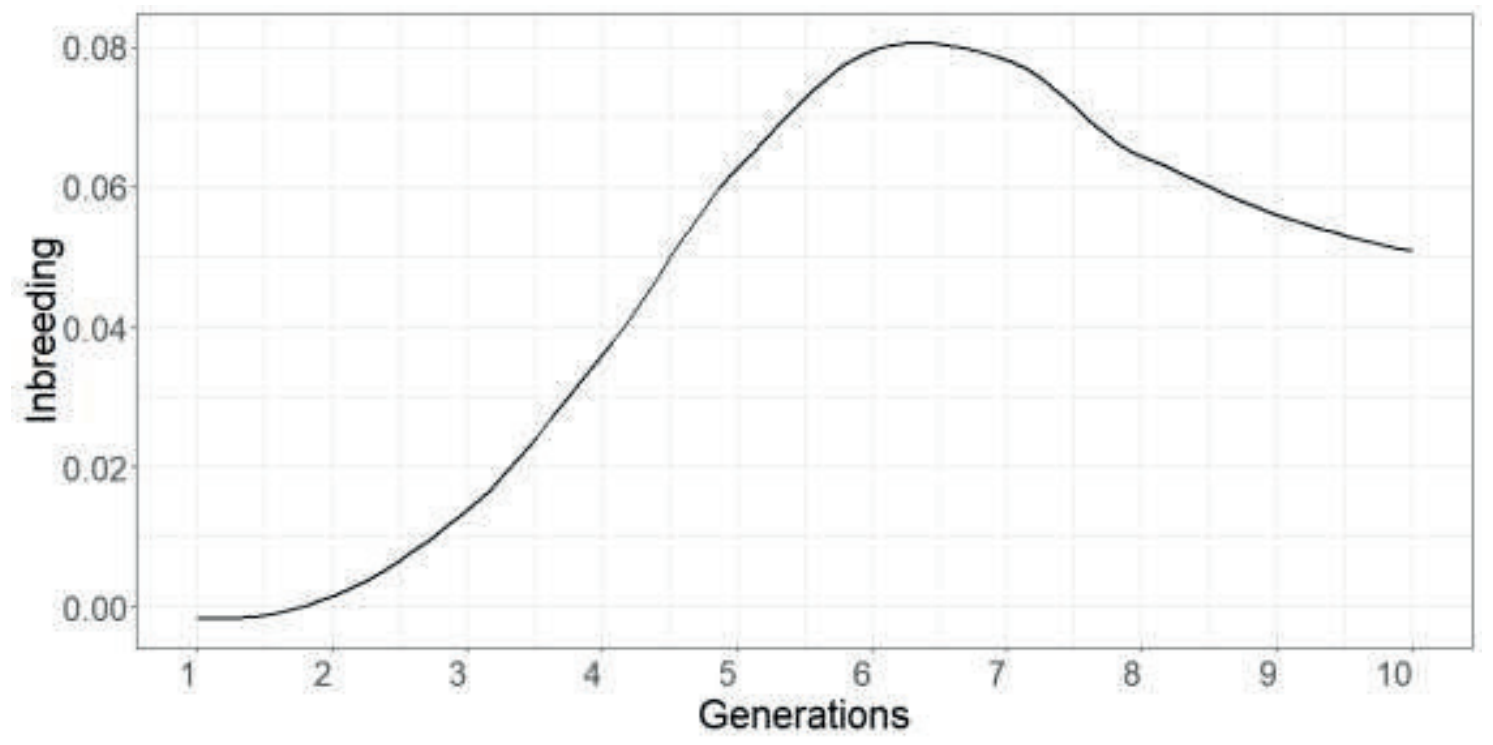

Figure 1. Inbreeding coefficient (F) for the pedigree of Blanco Orejinegro (BON) cattle from Colombia across 10 generations. 
In this study was $4.41 \%$; in previous studies, lower average inbreeding values were reported in the BON breed, e.g., in 2020, an average inbreeding coefficient of $1.3 \%$ was registered in a database of that included 4,523 animals (Ocampo Gallego, Ramírez Toro, Lopera Peña, Restrepo Castañeda, \& Gallego Gil, 2020). Similarly, in nonnative breeds such as Holstein and Brown Swiss from Switzerland high inbreeding values were reported $(5.7 \%$ and $7.1 \%$, respectively) (Signer-Hasler et al., 2017). High inbreeding leads to inbreeding depression, which is a reduction in the mean breeding values, especially of reproductive traits (Howard, Pryce, Baes, \& Maltecca, 2017).

Heritability was estimated for the reproductive traits evaluated. Table 1 shows the genetic parameters of the traits assessed in the current study (highlighted in bold) compared to other studies with other breeds. This table shows that the $\mathrm{Cl}$ in the BON population of the present study showed a low heritability of $0.11 \pm 0.03$. This means that $\mathrm{Cl}$ depends on the additive genetic variation of the animals to a minor percentage (11\%) and mostly (89\%) on other variation sources. Nonetheless, the repeatability of the trait was 0.15 . The heritability for $\mathrm{Cl}$ was similar to that reported in 2012 in BON cattle, an $\mathrm{h}^{2}$ value of $0.13 \pm 0.03$ and equal repeatability, with almost zero permanent environmental variance (M-Rocha et al., 2012); in the present study, the repeatability was higher $(0.15 \pm 0.04)$, showing a higher permanent environmental variance. Conversely, in Ethiopian Holstein, an $h^{2}$ value of $0.11 \pm 0.04$ (Ayalew, Aliy, \& Negussie, 2017) was registered; in Brown Swiss from Mexico, the heritability was 0.03 \pm 0.07 , and the repeatability was 0.12 (RíosUtrera, Robles, Fernández, \& Lagunes, 2010); and in Indubrazil cows, the $\mathrm{h}^{2}$ value was 0.13

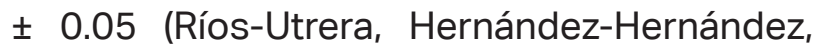
Villagómez Amezcua-Manjarréz, \& ZárateMartínez, 2013). Furthermore, in another study carried out in a population with pure BON individuals and crosses (BON $x$ Zebu and BON $x$ Angus $x$ Zebu), the heritability was $0.15 \pm 0.07$ (Vergara et al., 2008). Even lower heritability values for $\mathrm{Cl}$ have been published for breeds such as Romosinuano for the first calving interval $(0.06 \pm 0.06)$ and the second calving interval $(0.09 \pm 0.06)$, as different year ranges were used (Vergara, Ossa, Cabrera, Simanca, \& Pérez, 2016), as well as in Hanwoo with 0.01 \pm 0.05 (Lopez et al., 2019). This suggests that improving the $\mathrm{Cl}$ trait depends mainly on improving conditions such as feeding and environmental effects that contribute to female recovery; however, long-term genetic progress can be obtained. 


\section{Table 1}

Genetic parameters for reproductive traits in the Colombian creole cattle breed Blanco Orejinegro (BON) assessed in the current study compared with several nonnative breeds

\begin{tabular}{|c|c|c|c|c|c|c|c|}
\hline Trait & Breed & Author & $h^{2}$ & $\sigma_{\mathrm{a}^{2}}$ & $\sigma_{\mathrm{pe}}^{2}$ & $\sigma_{\mathrm{p}^{2}}$ & $\sigma_{\mathrm{e}^{2}}$ \\
\hline \multirow{5}{*}{$\mathrm{Cl}$} & BON & In this study & $0.11 \pm 0.03$ & $1,082.21$ & 459.88 & $10,195.32$ & $8,653.23$ \\
\hline & Crosses & Vergara et al. (2008) & $0.15+0.07$ & $1,107.51$ & 0.79 & $7,421.52$ & $6,323.21$ \\
\hline & BON & M-Rocha et al. (2012) & $0.13+0.03$ & 6.51 & 0.12 & 51.57 & 45.06 \\
\hline & Holstein & Ayalew et al. (2017) & $0.11 \pm 0.04$ & $1,483.02$ & $1,526.5$ & & 10,965 \\
\hline & Hanwoo & Lopez et al. (2019) & $0.03 \pm 0.01$ & 19.80 & 6.73 & 762.94 & 736.41 \\
\hline \multirow{4}{*}{ AFC } & BON & 2020 & $0.00 \pm 0.05$ & 1.00 & * & 24.49 & 24.48 \\
\hline & BON & M-Rocha et al. (2012) & $0.15+0.02$ & 157.16 & * & $1,061.17$ & 904.01 \\
\hline & Holstein & Ayalew et al. (2017) & $0.47 \pm 0.06$ & 22.7 & & & 25.9 \\
\hline & Hanwoo & Lopez et al. (2019) & $0.10 \pm 0.01$ & 427.78 & * & $4,128.10$ & $3,700.30$ \\
\hline \multirow{3}{*}{ GD } & BON & 2020 & $0.00 \pm 0.08$ & 0.02 & 0.00 & 112.78 & 112.76 \\
\hline & $\begin{array}{l}\text { Holstein } \\
\text { and Brown } \\
\text { Swiss }\end{array}$ & $\begin{array}{l}\text { Ríos-Ultrera, Vega- } \\
\text { Murillo, Calderón-Robles, } \\
\text { Galavíz-Rodríguez, \& } \\
\text { Lagunes-Lagunes. (2012) }\end{array}$ & $0.08+0.05$ & 5.03 & 0.00 & 63.28 & 57.98 \\
\hline & Hanwoo & Lopez et al. (2019) & $0.13 \pm 0.02$ & 3.59 & 1.57 & 27.63 & 22.47 \\
\hline
\end{tabular}

Heritability $\left(\mathrm{h}^{2}\right)$, additive genetic variance $\left(\sigma_{\mathrm{a}^{2}}\right)$, permanent environmental variance $\left(\sigma_{\mathrm{pe}}^{2}\right)$, phenotypic variance $\left(\sigma_{\mathrm{p}^{2}}\right)$, variance of the error $\left(\sigma_{\mathrm{e}^{2}}\right)$, calving interval $(\mathrm{Cl})$, age at first calving (AFC), gestation duration (GD), and maximum number of calvings ( $\mathrm{NCmax}$ ).

The heritability for AFC in this study was close to zero $(0.00 \pm 0.05)$. Torshizi (2016) reported a low $h^{2}$ value $(0.075 \pm 0.002)$ in Iranian Holstein cows. This result differs from what has been previously reported in BON cattle in a study carried out by M-Rocha et al. (2012). These authors found a heritability value of $0.15 \pm 0.02$ in this breed and an $h^{2}$ value of $0.15 \pm 0.13$ in $\mathrm{BON} \times$ Zebu crosses (Vergara et al., 2008). Moreover, in other studies, a heritability value of $0.21 \pm 0.005$ was found in Simmental (Amaya, Martínez, \& Cerón-Muñoz, 2020), and $0.18 \pm 0.02$ was found in the Japanese Black breed (Setiaji \& Oikawa, 2019). Even higher values have been registered in Ethiopian Holstein $\left(\mathrm{h}^{2}=0.47 \pm\right.$ 0.06) (Ayalew et al., 2017). These results reflect that genetic improvement of the AFC trait in the Colombian BON breed will be difficult and, in turn, implies that enhanced nutrition and proper management of cows will contribute to improving this trait.

The gestational duration $0.00 \pm$ 0.08) was close to zero in BON females from Colombia (Table 1). This result agrees with the low values found by other authors. In Holstein and Brown Swiss females, $h^{2}$ values of $0.08 \pm$ 0.05 were recorded (Ríos-Utrera et al., 2013), and in the Japanese Black breed, the value was $0.08 \pm 0.02$ (Setiaji \& Oikawa, 2019). However, the result found in the current study differs from another with Nellore cows from Brazil, where heritability was higher $(0.10 \pm$ 0.01) (Ulhôa Magnabosco, Brito Brito Lopes, Magalhaes Rosa, \& Sainz, 2016). GD is a trait 
that, in addition to being affected by extreme environmental conditions, may also be affected by maternal, fetal, genetic, and other environmental factors.

The genetic and phenotypic trends for the evaluated traits are presented below. These were established according to the grouping year of the mean breeding value estimation for each reproductive trait assessed. As shown in Figure $2(\mathrm{~A})$, for $\mathrm{Cl}$, the genetic trend was negative $(p<0.05)$, showing a genetic progress value of -0.01 days/year $\left(R^{2}=0.47\right)$; this result indicates a low level of reduction over the years. However, as shown in Figure 2 (B), the phenotypic trend was positive at 0.31 days/ year $\left(R^{2}=0.02\right)$, indicating that, for this trait, the highest variability proportion is given by environmental changes throughout the years. In other breeds where selection is stronger, a higher $\mathrm{Cl}$ reduction is seen, such as in Holstein cattle from Brazil (21.4 days/year) (Teixeira, Freitas, \& Ribas, 1994). A possible explanation for the genetic trend behavior in this study is that the selection implemented in recent years has produced minor improvements in the BON population; however, a positive environmental factor affecting the average female performance was present during the years assessed.
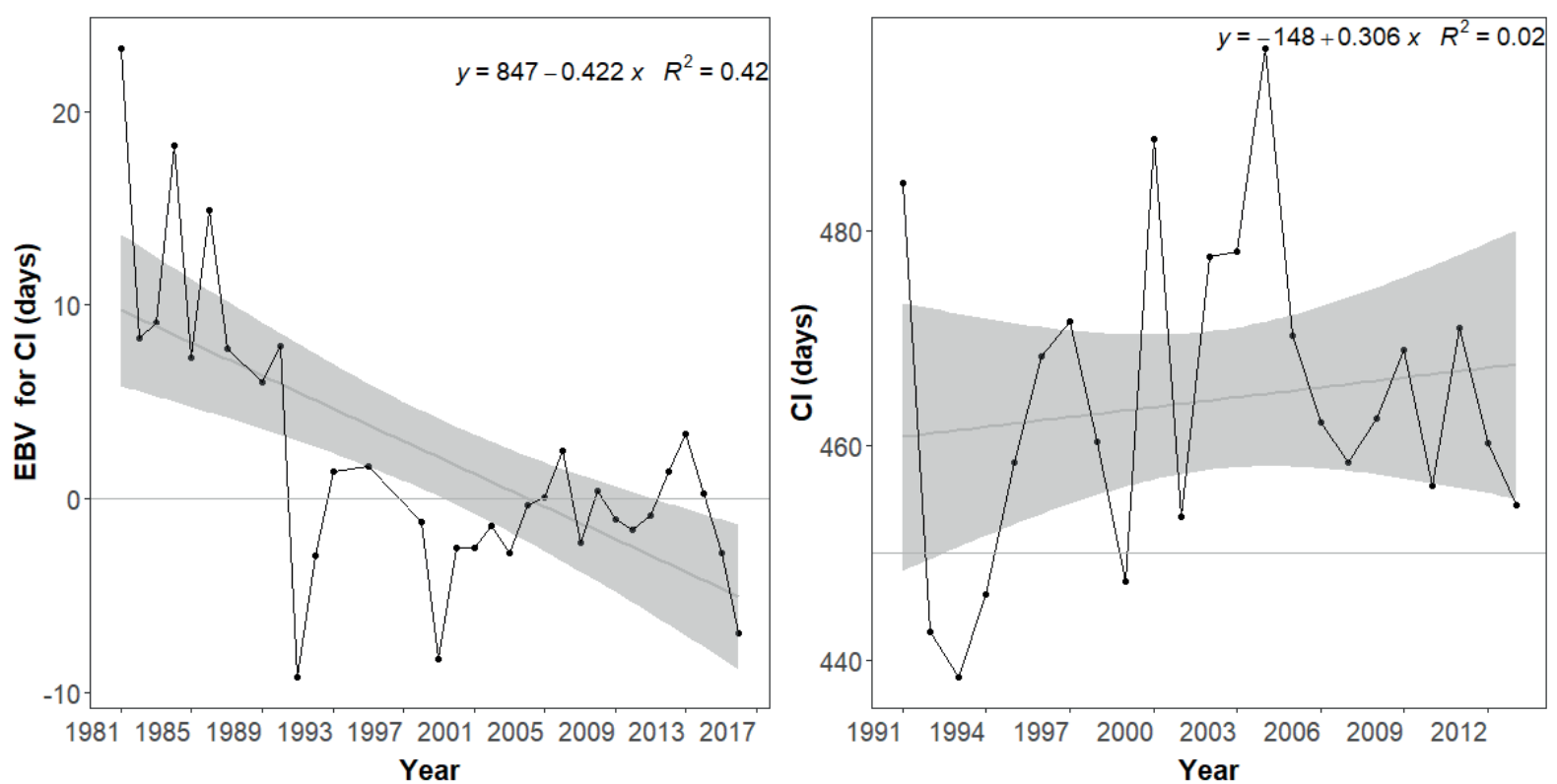

Figure 2. Genetic $(A)$ and phenotypic $(B)$ trends per year for the trait calving interval $(\mathrm{Cl})$ in Blanco Orejinegro (BON) females from Colombia. EBV: estimated breeding values

Regarding the analysis of the relationship between inbreeding and breeding values for $\mathrm{Cl}$, an inbreeding depression effect was found for this trait. An increase of 0.43 days in inbreeding depression was observed between calving intervals due to an increase of $1 \%$ in inbreeding. Consequently, inbred animals $(F>0)$ had an average breeding value with a $\mathrm{Cl}$ of $9.89 \pm 26$ days and $0.17 \pm 0.38$ days for noninbred animals (Figure 3 ). 
This means that increased inbreeding raises the $\mathrm{Cl}$ in the population. In addition, inbreeding might have an adverse effect on milk production, fertility, and survival (Mc Parland, Kearney, Rath, \& Berry, 2007). Studies in specialized breeds report a similar behavior. Regarding intervals in Holstein cows, a $1 \%$ increase in inbreeding was associated with an extension of $\mathrm{Cl}$ of $+0.22 \pm 0.17$ days (Pryce, Haile-Mariam, Goddard, \& Hayes, 2014). In contrast, in the study by AguirreValverde et al. (2013) in Holstein and Jersey cows in Costa Rica, animals with low levels of inbreeding had, on average, an 18 days lower $\mathrm{Cl}$ than more inbred animals (Pryce et al., 2014). Thus, inbreeding depression causes a decrease in animal performance. The decline in the frequency of heterozygous individuals represents a risk, not only in reproduction programs but also in the conservation of the creole resource. This highlights the importance of carrying out inbreeding control programs in BON cattle in Colombia to contribute to the conservation of this unique genetic resource.

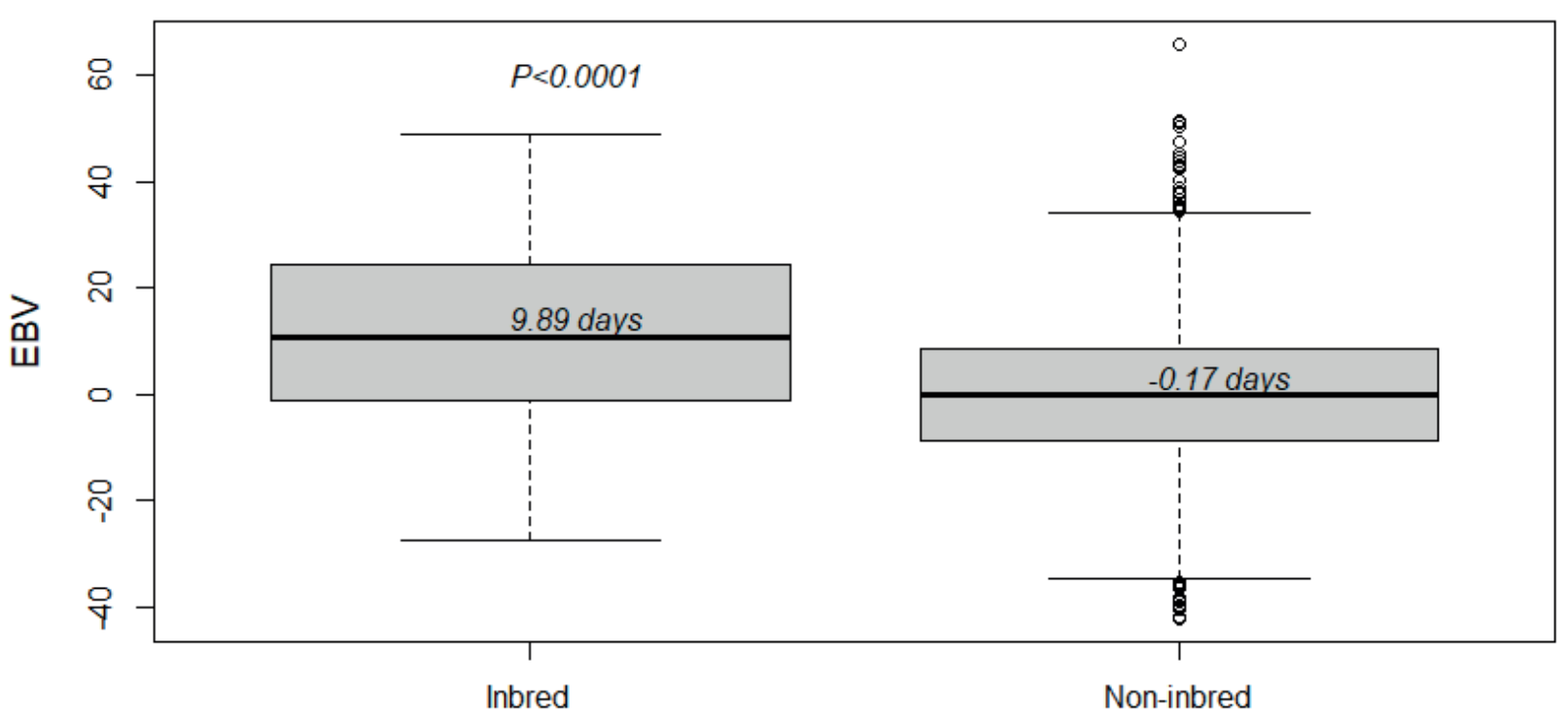

Inbreeding

Figure 3. Inbreeding depression for the trait calving interval in Blanco Orejinegro (BON) cattle. Boxplot of estimated breeding values (EBV) according to inbreeding: inbred ( $\mathrm{P}>0$ ) or noninbred $(F=0)$.

\section{Conclusions}

The Colombian creole BON cattle breed shows good reproductive performance when compared with other native and commercial breeds. However, it also shows significant levels of inbreeding (4.41\%), but this is lower compared to previous reports on this breed as well as in other specialized breeds.

The reproductive traits evaluated, except for NCmax, have low heritability, implying that genetic progress could be slow since they are highly dependent on the environment. 
The genetic trends for $\mathrm{Cl}$ and NCmax were negative and showed variability throughout the years. Finally, inbreeding depression for $\mathrm{Cl}$ caused an increase of 0.43 days in the calving interval for each increase of $1 \%$ in the inbreeding coefficient. According to the results presented, it is crucial to establish practices that guarantee good environmental management in the BON cattle herds of Colombia to improve reproductive efficiency.

More research should be done with a larger sample size for each parameter, especially NCmax, to improve the trait estimates; however, there is still a significant environmental influence on reproductive traits.

\section{Acknowledgments}

To MINCIENCIAS for funding the research project, "Knowing our creole resources: genomic analysis and search for genome regions associated with productive, reproductive and health traits in Blanco Orejinegro cattle (BON)" [code 110177658049, CT 015-2018]. Through resources allocated by this project, information collection was achieved, as well as the financing of the postgraduate degree of one of the authors. Many thanks to the participating BON livestock producers for supplying the information of their herds and to Universidad Nacional de Colombia sede Medellín and Universidad Tecnológica de Pereira, who carried out this project, from which this manuscript was derived.

\section{References}

Aguirre-Valverde, J., Vargas-Leitón, B., \& Romero-Zuñiga, J. J. (2013). Efectos de la endogamia sobre parámetros reproductivos en vacas Holstein y Jersey deCostaRica.AgronomíaMesoamericana, 24(2), 245. doi: 10.15517/am.v24i2.12523

Amaya, A., Martínez, R., \& Cerón-Muñoz, M. (2020). Parámetros genéticos para crecimiento y reproducción en ganado Simmental mediante parentesco por pedigríy genómico. Revista MVZ Córdoba, 25(1), 1-8. doi: 10.21897/rmvz.1520

Ayalew, W., Aliy, M., \& Negussie, E. (2017). Estimation of genetic parameters of the productive and reproductive traits in Ethiopian Holstein using multi-trait models. Asian-Australasian Journal of Animal Sciences, 30(11), 1550. doi: 10. 5713/ajas.17.0198

Boldman, K. G., Kriese, L. A., Van Vleck, L. D., \& Kachman, S.D. (1995). A manual for use of MTDFREML: A set of programs to obtain estimates of variances and covariances (pp. 1-112). Olay Centre, Nebraska, USA: US Department of Agriculture, Agricultural Research Service. http://www.zzlab.net/ MTDFREML/index.html

Canaza-Cayo, A. W., Lopes, P. S., Cobuci, J. A., Martins, M. F., \& Silva, M. V. G. B. da. (2018). Genetic parameters of milk production and reproduction traits of Girolando cattle in Brazil. Italian Journal of Animal Science, 17(1), 22-30. doi: 10. 1080/1828051X.2017.1335180

Eler, J. P., Bignardi, A. B., Ferraz, J. B. S., \& Santana, M. L. Jr. (2014). Genetic relationships among traits related to reproduction and growth of Nelore females. Theriogenology, 82(5), 708-715. doi: 10. 1016/j.theriogenology.2014.06.001 
González Herrera, L. G., Rincón Flórez, J. C., González Corrales, J. C., Londoño Gil, M., Caivio Nasner, S. L., Saldarriaga Saldarriaga, A., \& López Herrea, A. (2020). Evaluación genética de ganado Blanco Orejinegro $(B O N)$ de Colombia. Colombia: Universidad Nacional de Colombia.

Howard, J. T., Pryce, J. E., Baes, C., \& Maltecca, C. (2017). Invited review: Inbreeding in the genomics era: inbreeding, inbreeding depression, and management of genomic variability. JournalofDairyScience, 100(8), 6009-6024. doi: 10.3168/jds.2017-12787

Kern, E. L., Cobuci, J. A., Costa, C. N., Neto, J. B., Campos, G. S., \& McManus, C. M. (2014). Genetic parameters for longevity measures in Brazilian Holstein cattle using linear and threshold models. Archives Animal Breeding, 57(1), 1-12.doi: 10.7482/0003-9438-57-033

Lopez, B. I., Son, J.-H., Seo, K., \& Lim, D. (2019). Estimation of genetic parameters for reproductive traits in Hanwoo (Korean Cattle). Animals, 9(10), 715. doi: 10.3390/ ani9100715

M-Rocha, J. F., Gallego, J. L., Vásquez, R. F., Pedraza, J. A., Echeverri, J., Cerón-Muñoz, M. F., \& Martínez, R. (2012). Estimation of genetic parameters for age at first calving and calving interval in Blanco Orejinegro (BON) breed cattle populations in Colombia. Revista Colombiana de Ciencias Pecuarias, 25(2), 220-228.

Martínez-Rocha, R. E., Ramírez-Valverde, R., Núñez-Domínguez, R., García-Muñiz, J. G., \& Parra-Bracamonte, G. M. (2021). Comportamiento de crecimiento y reproductivo en hembras bovinas Romosinuano. Revista MVZ Córdoba, 26(1), e2033-e2033. doi: 10.21897/rmvz.2033
Martínez, A., Gama, L. T., Cañón, J., Ginja, C., Delgado, J. V, Dunner, S.,... Rodellar, C. (2012a). Genetic footprints of Iberian cattle in America 500 years after the arrival of Columbus. PLoS One, 7(11), e49066. doi: 10.1371/journal.pone.0049066

Martínez, J. L. L., Bernal, J. H. Q., Blanquicet, J. L. G., \& Sarraz, G. A. O. (2020). Efecto de caracteres propios e inherentes al animal sobre la edad al primer parto en la hembra bovina de la raza Romosinuano. Revista de la Facultad de Ciencias, 9(2), 6-22. doi: 10.15446/rev.fac.cienc.v9n2.79322

Martínez, S., Rodrigo, E., Vásquez, R., Gallego, G., Gómez, Y., Jaime L.,... Quiceno, J. (2012b). Eficiencia productiva de la raza Bon en el trópico colombiano. Bogotá (Cundinamarca): Corpoica.

Mc Parland, S., Kearney, J. F., Rath, M., \& Berry, D. P. (2007). Inbreeding effects on milk production, calving performance, fertility, and conformation in Irish HolsteinFriesians. Journal of Dairy Science, 90(9), 4411-4419. doi: 10.3168/jds.2007-0227

Mrode, R., \& Thompson, R. (2014). Linear models for the prediction of animal breeding values (3nd ed.). Trowbridge: CABI Publishing.

Ocampo Gallego, R., Ramírez Toro, J., Lopera Peña, J., Restrepo Castañeda, G., \& Gallego Gil, J. (2020). Genetic diversity assessed by pedigree analysis in the Blanco Orejinegro (BON) cattle breed population from the colombian germplasm bank. Chilean Journal of Agricultural \& Animal Sciences, 36(1), 69-77. doi: 10.29393/ CHJAAS36-4D30004

Ossa-Saraz, G. A. (1999). Comportamiento productivo del ganado Costeño con 
Cuernos y sus cruces. Santafé de Bogotá: CO-BAC. (Doc. 19125).

Pryce, J. E., Haile-Mariam, M., Goddard, M. E., \& Hayes, B. J. (2014). Identification of genomic regions associated with inbreeding depression in Holstein and Jersey dairy cattle. Genetics Selection Evolution, 46(1),1-14. doi: 10.1186/s127 11-014-0071-7

Quijano, J. H., \& Echeverri, J. J. (2016). Genética cuantitativa aplicada al mejoramiento animal. Bogotá: Universidad Nacional de Colombia. Recuperado de https:// www.uneditorial.com/bw-geneticacuantitativa-aplicada-al-mejoramientoanimal-biologia.html\#mas-info

$\mathrm{R}$ Core Team (2019). A language and environment for statistical computing. Vienna, Austria: Foundation for Statistical Computing. Retrieved from https://www. R-project.org/

Ríos-Utrera, Á., Vega-Murillo, V. E., CalderónRobles, R. C., Galavíz-Rodríguez, J. R., \& Lagunes-Lagunes, J. (2012). Genetic analysis of milk yield of holstein and brown swiss cows under intensive grazing in subtropical conditions. Revista Cientifica de La Facultad de Ciencias Veterinarias de La Universidad Del Zulia, 22(6), 545552.

Ríos-Utrera, Á., Robles, R. C. C., Fernández, J. V. R., \& Lagunes, J. L. (2010). Estimation of genetic parameters for fertility traits in Brown Swiss cattle under subtropical conditions of Mexico. Veterinaria México, 41(2), 117-129.

Ríos-Utrera, Á., Hernández-Hernández, V. D., Villagómez Amezcua-Manjarréz, E., \& Zárate-Martínez, J.P.(2013). Heredabilidad de características reproductivas de vacas Indubrasil. Agronomía Mesoamericana, 24(2), 293-300.

Rojas-Downing, M. M., Nejadhashemi, A. P., Harrigan, T., \& Woznicki, S. A. (2017). Climate change and livestock: impacts, adaptation, and mitigation. Climate Risk Management, 16, 145-163. doi: 10.1016/j. crm.2017.02.001

Saraz, G. O., Hinestroza, A. D., Rodríguez, M. O. S., Reza, S., García, J. P., \& Pérez, Y. A. (2013). Formación, desarrollo y caracterización fenotípica de los caracteres productivos y reproductivos del hato Romosinuano del banco de germoplasma de Colombia. Ciencia y Tecnología Agropecuaria, 14(2), 231-243.

Sebastian, J., \& Correa, P. (2016). Evaluación comparativa de parámetros productivos y reproductivos en ganado Brahmán gris y rojo en un hato puro en Barinas-Venezuela. Recuperado de https://ciencia.lasalle.edu. co/zootecnia/5

Segura-Correa, J. C., Magaña-Monforte, J. G., Aké-López, J. R., Segura-Correa, V. M., Hinojosa-Cuellar, J. A., \& Osorio-Arce, M. M. (2017). Breed and environmental effects on birth weight, weaning weight and calving interval of Zebu cattle in Southeastern Mexico. Tropical and Subtropical Agroecosystems, 20(2), 297305.

Setiaji, A., \& Oikawa, T. (2019). Genetics of heifer reproductive traits in Japanese Black cattle. Asian-Australasian Journal of Animal Sciences, 33(2), 197-202. doi: 10.1080/02626667.2013.819433

Signer-Hasler, H., Burren, A., Neuditschko, M., Frischknecht, M., Garrick, D., Stricker, C.,... 
Flury, C. (2017). Population structure and genomic inbreeding in nine Swiss dairy cattle populations. Genetics Selection Evolution, 49(1), 1-13 doi: 10.1186/s12 711-017-0358-6

Teixeira, N. M., Freitas, A. F., \& Ribas, N. P. (1994). Tendências genéticas em rebanhos da raça Holandesa no Estado do Paraná. II. Idade ao primeiro parto e primeiro intervalo de partos. Revista de la Sociedade Brasileira de Zootecnia, 23(6), 992-1001.

Torshizi, M. E. (2016). Effects of season and age at first calving on genetic and phenotypic characteristics of lactation curve parameters in Holstein cows. Journal of Animal Science and Technology, 58(1), 8. doi: 10.1186/s40781-016-0089-1

Ulhôa Magnabosco, C., Brito Lopes, F., Magalhaes Rosa, G. J. de, \& Sainz, R. D. (2016). Bayesian estimates of genetic parameters for reproductive traits in Nellore cows raised on pasture in tropical regions. Revista Colombiana de Ciencias Pecuarias, 29(2), 119-129. doi: 10.17533/ udea.rccp.v29n2a05
United States Department of Agriculture (2017). AIP, Animal improvement program (Last Modified: 01/12/2017). Washington, DC: Barc-West, Building.

Valencia, J. A. C., Aristizabal, P. A. R., Carmona, K. V. Z., Martínez, J. L. L., \& Herrera, L. G. G. (2016). Factores ambientales relacionados con el peso al parto, el peso al destete y el intervalo entre partos en vacas blanco orejinegro y brahman. FAGROPEC-Facultad de Ciencias Agropecuarias, 8(2), 68-72.

Vergara, O., Cerón, M., Hurtado, N., Arboleda, E., Granada, J., \& Rúa, C. (2008). Estimación de la heredabilidad del intervalo de partos en bovinos cruzados. Revista MVZ Córdoba, 13(1), 1192-1196.

Vergara, O., Ossa, G., Cabrera, J., Simanca, J., \& Pérez, J. (2016). Heritabilities and genetic trends for reproductive traits in a population of Romosinuano cattle in Colombia. Revista MVZ Córdoba, 21(1), 5250-5257.

Wright, S. (1922) Coefficients of inbreeding and relationship. American Naturalist, 56(645), 330-338. doi: 10.1086/279872 
